\title{
CONTROLE JUDICIAL DAS DECISÕES DOS TRI- BUNAIS DE CONTAS. QUAIS SÃO OS LIMITES DA ATUAÇÃO DO TRIBUNAL DE CONTAS?
}

\section{JUDICIAL CONTROL OF COURT OF AUDITORS 'DECISIONS. WHAT ARE THE LIMITS OF THE COURT OF AUDITORS 'PERFORMANCE?}

\author{
Eliton Carlos Ramos Gomes ${ }^{1}$
}

Resumo: Objetivou-se com este artigo discutir o controle judicial das decisões dos tribunais de contas, assim como seus limites de atuação. A metodologia empregada foi a pesquisa bibliográfica, tendo como amostra livros e periódicos jurídicos que tratam do tema, a busca foi realizada em bibliotecas físicas e online. A discussão do abordou o delinear histórico dos tribunais de contas em alguns países tendo destaque o Tribunal de Contas da França, por ser o modelo seguido pelo TCU brasileiro. Discute-se a evolução cronológica da formação dos Tribunais de Contas no Brasil, desde os tempos da colonização até a edição da Constituição Federal de 1988, mostrando a estrutura organizacional e atuação do TCU, dentro do que estabelece o artigo 71 da Constituição Federal de 1988. Também, se descreve as funções dos Tri-

1 Bacharel em Direito, Pós-graduando em Direito Público, Membro da Comissão do Advogado Publicista da OAB/MS, Sócio do Escritório Ramos Gomes Advocacia e Consultoria Jurídica - Campo Grande/MS

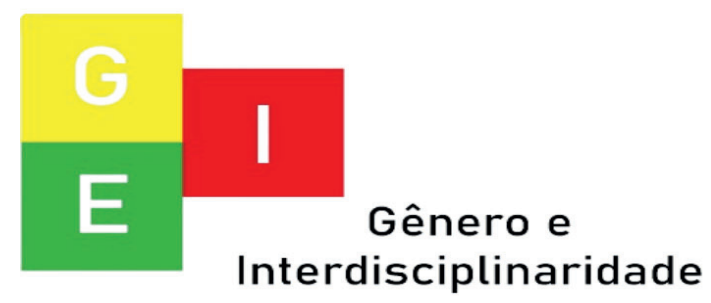


ISSN: 2675-7451

Vol. 02 - n 03 - ano 2021

Editora Acadêmica Periodicojs

bunais de Contas, que são fiscalizar, consultar, informar, judicar, sancionar, corrigir, normatizar e ouvir, educar e orientar. Ainda, demonstra-se a atuação jurisdicional dos tribunais de Contas, exemplificando com citações doutrinárias e jurisprudenciais, quanto ao controle judicial das decisões dos tribunais de contas é apresentado um panorama dos entendimentos doutrinários e jurisprudenciais, casos de revisão das decisões dos Tribunais de Contas pelo Judiciário. Concluiu-se que a jurisprudência moderna inovou ao revisar julgados do Tribunal de Contas tendo como base os princípios da proporcionalidade, moralidade, eficiência e teoria dos motivos determinantes, assim como o princípio da inafastabilidade da tutela jurisdicional. Enfim, os Tribunais de Contas podem ter suas decisões revisadas pelo Poder Judiciário, tanto nos aspectos formais como materiais.

Palavras-Chave: Tribunal de Contas. Competências. Limites.

Abstract: The objective of this article was to discuss the judicial control of the decisions of the courts of auditors, as well as their limits of performance. The methodology used was the bibliographic research, having as sample books and legal journals that deal with the theme, the search was carried out in physical and online libraries. The discussion of the work revolved around the history of the courts of accounts in some countries, with the Court of Accounts of France being highlighted, as it is the model followed by the Brazilian TCU. It discusses the chronological evolution of the formation of the Court of Accounts in Bra-

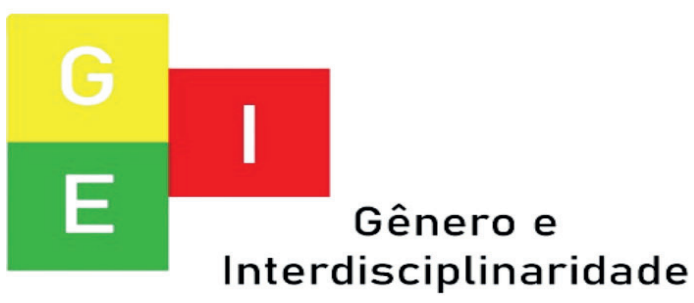


ISSN: 2675-7451

Vol. 02 - n 03 - ano 2021

Editora Acadêmica Periodicojs

zil, from the time of colonization to the edition of the Federal Constitution of 1988, showing the organizational structure and performance of the TCU, within the scope of Article 71 of the Federal Constitution of 1988 Also, the functions of the Courts of Accounts are described, which are to supervise, consult, inform, judge, sanction, correct, standardize and listen, educate and guide. Still, the judicial performance of the courts of Auditors is demonstrated, exemplifying with doctrinal and jurisprudential citations, regarding the judicial control of the decisions of the courts of accounts, an overview of the doctrinal and jurisprudential understandings is presented, showing cases of review of the decisions of the Courts of Accounts by the Judiciary. It was concluded that the modern jurisprudence innovated when reviewing judgments of the Court of Auditors based on the principles of proportionality, morality, efficiency and theory of the determinant reasons, as well as the principle of unfastening jurisdictional protection. Finally, the Courts of Accounts can have their decisions reviewed by the Judiciary, both in formal and material aspects.

Keywords: Court of Auditors. Skills. Limits.

\section{INTRODUÇÃO}

O Tribunal de Contas é uma instituição de suma importância para a transparência do sistema de gestão contábil e financeira pública. São instituições especializadas em inspeção das contas públicas nos diferentes órgãos da Administração Pública, na esfera municipal, esta-

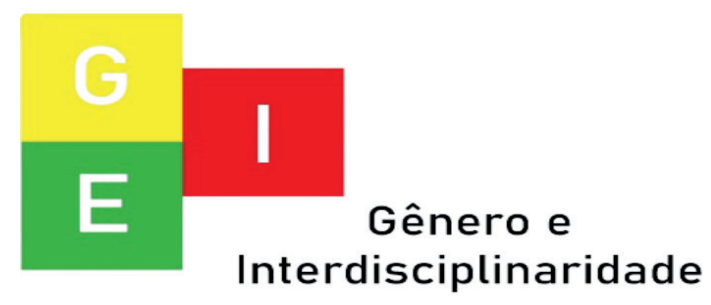


ISSN: 2675-7451

Vol. 02 - n 03 - ano 2021

Editora Acadêmica Periodicojs

dual e federal. A função desses

tribunais é analisar, fiscalizar e

controlar as contas públicas (con-

tábil, financeira, orçamentária, operacional e patrimonial) em todo o território nacional, essa função também é denominada de controle externo.

A Constituição Federal de 1988 preconiza no artigo 71 que cabe ao Tribunal de Contas da União auxiliar o Congresso Nacional no controle externo, fazendo a fiscalização contábil, financeira e orçamentária dos entes públicos. No entanto, cada esfera de governo tem o seu controle externo, ou seja, na união, nos estados e municípios, os tribunais de conta atuam dentro da sua jurisdição e conforme orientação da legislação.

No artigo 31 da Carta Magna verifica-se que a fiscalização externa das contas municipais, de acordo com o parágrafo $1^{\mathrm{o}}$ ficará a cargo da Câmara $\mathrm{Mu}$ nicipal, auxiliada pelo "Tribunal de Contas do Estado ou do Município ou dos Conselhos ou Tribunais de Contas dos Municípios, onde houver", ficando claro que os municípios que não possuem esses tribunais, não poderão cria-los, pois é isso que determina o parágrafo $4^{\circ}$ desse artigo.

Levando em consideração a importância do Tribunal de Contas para uma administração transparente e responsável, este artigo tem como objetivo discutir o controle judicial das decisões dos tribunais de contas, assim como seus limites de atuação.

O artigo está dividido em introdução, capítulo $1^{\circ}$, trazendo um breve história dos tribunais de contas em alguns países, enfocando a história do tribunal de contas no Brasil; no capítulo $2^{\circ}$ dispõe sobre a atuação do tribunal de contas da

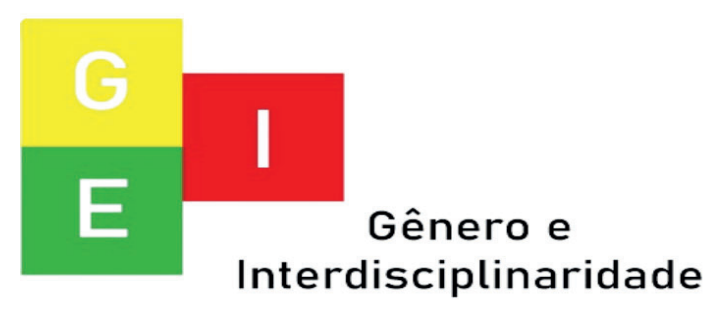


ISSN: 2675-7451

Vol. 02 - n 03 - ano 2021

Editora Acadêmica Periodicojs

união, assim como as suas funções; no capítulo $3^{\circ}$ discute-se a atuação jurisdicional do tribunal de contas; no capítulo $4^{\circ}$ enfoca o controle judicial das decisões dos tribunais de contas; fecha o trabalho apresentado as considerações finais e a lista de referências, consultadas e citadas durante o desenvolvimento do trabalho.

\section{A IMPORTÂNCIA HISTÓ-} RIA DOS TRIBUNAIS DE CONTAS E SEU DESENVOLVIMENTO DO OCIDENTE

O Tribunal de contas instituído no Brasil segue o modelo francês, que foi adotado por diferentes países em todo o mundo, assim, além de seguir as normas jurídicas tradicionais do próprio pais, o controle financeiro da União segue o modelo francês (MELO, 2011). O modelo de Tribunal de Contas é de um órgão colegiado, em que os membros têm função análogas aos membros do Poder Judiciário, com objetivo de analisar e controlar a legalidade dos atos administrativos. No Brasil o modelo adotado para o Tribunal de Contas é de: [...] planejamento, orçamento, execução e controle, portanto, os governantes devem utilizar ações para o controle efetivo das contas públicas, mantendo-as sob fiscalização, uma vez que se tratam de recursos advindos da sociedade, gerenciados por agentes públicos em prol da comunidade de um país, portanto, seu uso não deve ser arbitrário e irresponsável (BARRETO, 2016, p. 6).

Voltando ao processo histórico na França, o tribunal de contas foi adotado a partir de

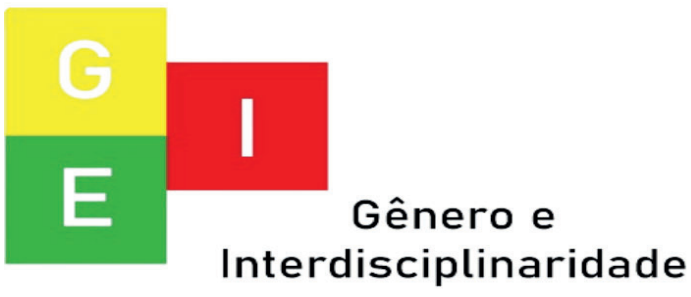


ISSN: 2675-7451

Vol. 02 - n 03 - ano 2021

Editora Acadêmica Periodicojs

alguns eventos como as perdas ocorridas nas contas fiscais do reino da França durante a batalha que Richard I da Inglaterra liderou contra Philippe II da França, em 1194 no condado de Blois, o soberano inglês assumiu o controle dos cofres que continham as contas do reino da França e se recusou a devolvê-las, assim a decisão de prestar contas foi tomada por Philippe II, que criou uma Câmara de Contas embrionária (JEAN, 2013).

Em 1256 uma comissão da corte do rei foi mencionada em uma ordenança de Saint Louis. Ele prescreve que os "mayeurs et prud'hommes" (os prefeitos) da Alta- Normandia elaboram contas anuais e lhe enviaram. Alguns anos depois, em 1303, a Câmara de Contas de Paris, sucedeu à Corte do Rei em questões financeiras, e foi instalada no Palais de la Cité, onde permaneceu até a
Revolução. Sendo que a primeira organização oficial emergiu da ordenança de Philippe V da França, em 1320 (JEAN, 2013).

Após a Revolução, o Escritório de Contabilidade criado pela Assembleia Constituinte, foi transformado em uma Comissão de Contabilidade, mas não tinha autoridade nem os meios para garantir a regularidade dos fundos públicos. E a organização financeira do governo não dispunha de uma instituição capaz de dar garantias suficientes no manuseio de fundos públicos (JEAN, 2013).

E foi em 1807 que o Imperador francês Napoleão Bonaparte criou o Tribunal de Contas, como um órgão centralizado para o controle de contas públicas. O estabelecimento do Tribunal de Contas e a adoção de um código comercial foram os atos legislativos mais importantes

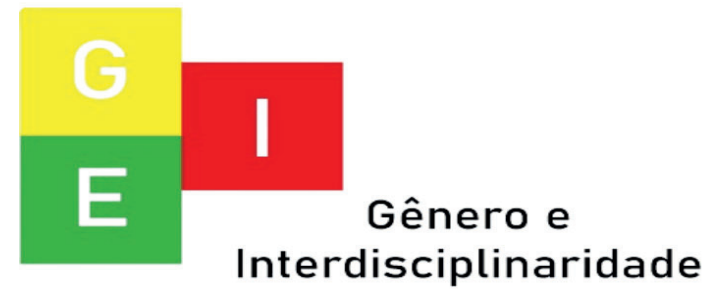


ISSN: 2675-7451

Vol. 02 - n 03 - ano 2021

Editora Acadêmica Periodicojs

desde 1807. Em 5 de setembro de 1807, os Conselheiros de Estado Jacques Defermon, Jean Bérenger e Jaubert foram instruídos a apresentar, em nome do Imperador o projeto de lei que criou o Tribunal de Contas Francês (JEAN, 2013).

No contexto histórico, a criação do Tribunal de Contas pelo Imperador Francês Napoleão Bonaparte tinha como função estabelecer um órgão de controle dos serviços estatais que fosse efetivamente independente dos serviços controlados. No entanto, na época, apenas o modelo judicial tornou possível garantir essa independência, essa foi a principal razão pela qual o Tribunal de Contas viu sua organização definida no modelo do Tribunal de Cassação (JEAN, 2013).

Os processos analisados pelo Tribunal de Contas da França eram secretos, escrito e obje- tivo, sendo o princípio contraditório mantido apenas pela regra do duplo julgamento. No entanto, em 2006 o Tribunal Europeu dos Direitos Humanos, no acórdão Martinie, considerou que o procedimento secreto do Tribunal de Contas violava o artigo $6, \S 1$, da Convenção Europeia dos Direitos Humanos. Foi então que por meio da Lei ${ }^{\circ}$ 1091/ 2008, reformulou as regras e procedimentos de atuação do Tribunal de Contas Francês, eliminando a regra do duplo julgamento, sendo a natureza contraditória garantida pela publicidade da audiência assim que as acusações fossem confirmadas (JEAN, 2013).

Na Alemanha, o primeiro escritório de auditoria foi fundado em 1714 pelo rei Friedrich Wilhelm I, como uma Câmara Geral de Computação, em 1723 foi convertida em uma Câmara Superior de Computação para

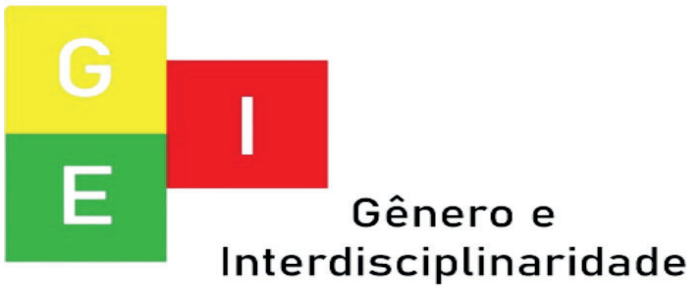


ISSN: 2675-7451

Vol. 02 - n 03 - ano 2021

Editora Acadêmica Periodicojs

Guerra e Domínio e continuou até 1945. Em 1868, passou para Tribunal de Contas da Confederação da Alemanha do Norte e em 1871 foi denominado de Tribunal de Contas do Reich alemão. Após a guerra, em 1948 foi criado o Tribunal de Contas da Área Econômica Unida e em 1950 passou a denominação de Tribunal de Contas Federal (ALEMANHA, 2020).

Nos Estados Unidos, o Gabinete de Prestação de Contas do Governo é uma agência governamental do ramo legislativo de controle externo que fornece serviços de auditoria, avaliação e investigação para o Congresso dos Estados Unidos. É a instituição suprema de auditoria do governo federal dos Estados Unidos. Em 1921 foi estabelecido o Escritório Geral de Contabilidade pela Lei de Orçamento e Contabilidade de 1921. O ato exigia que esse escri- tório investigasse na sede do governo ou em qualquer outro lugar, todos os assuntos relacionados ao recebimento, desembolso e aplicação de fundos públicos. Os auditores do Gabinete de Prestação de Contas do Governo realizam, além de auditorias financeiras, outras auditorias de desempenho das estatais. O Gabinete de Prestação de Contas do Governo é liderado pela Controladoria Geral dos EUA, uma posição profissional e não partidária no governo (EUA, 2020).

O Tribunal de Contas Europeu foi criado pelo Tratado de Bruxelas, em 22 de julho de 1975, e iniciou suas atividades em outubro de 1977, com sede no Luxemburgo. O TCE tem competência de auditor externo das contas da União Europeia. O TCE está sediado em Luxemburgo. Desde o início, o objetivo do TCE sempre foi melhorar a ma-

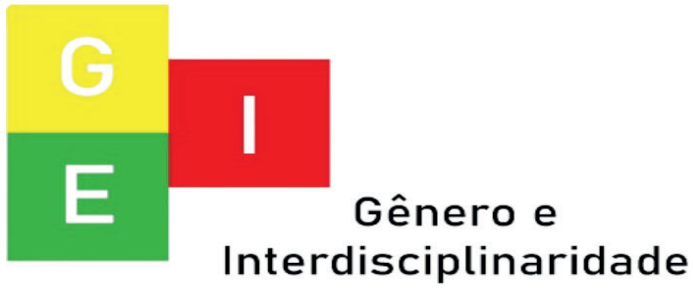


ISSN: 2675-7451

Vol. 02 - n 03 - ano 2021

Editora Acadêmica Periodicojs

neira como as finanças da União são gerenciadas e contribuir para a responsabilidade pública em relação ao aumento e gasto do orçamento da União Europeia por meio de garantia e consultoria (TCE, 2020).

História do Tribunal de Contas no Brasil

Historicamente o Tribunal de Contas, no Brasil, tem início com a colonização, aproximadamente em 1680 foram criadas as Juntas das Fazendas das Capitanias e a Junta da Fazenda do Rio de Janeiro, as quais estavam sob à jurisdição da coroa portuguesa. Foi a partir de 1808 , quando D. João VI veio para o Brasil, que foi criado o Conselho da Fazenda, que tinha como função acompanhar as despesas públicas.

Em 1822 com a Inde- pendência do Brasil, em 1824 foi instituída a primeira Constituição Brasileira, a partir de determinação constitucional o Erário Régio foi transformado em Tesouro Público, criando assim, os primeiros orçamentos relacionados aos gastos públicos e a contabilização dos mesmos. Em 1826, um projeto de lei foi apresentado ao Senado Imperial, pelos parlamentares Felisberto Caldeira Brandt e José Inácio Borges, com intuito de criar um Tribunal de Contas (SANTOS; QUEIROZ, 2013).

Com a queda do Império e a instituição da República ocorreram reformas político-administrativas, que resultaram na criação do Tribunal de Contas da União, em 7 de novembro de 1890, por meio do Decreto $\mathrm{n}^{\circ}$ $966^{\mathrm{a}}$, deliberado pelo então Ministro da Fazenda, Rui Barbosa, tendo como base os "princípios

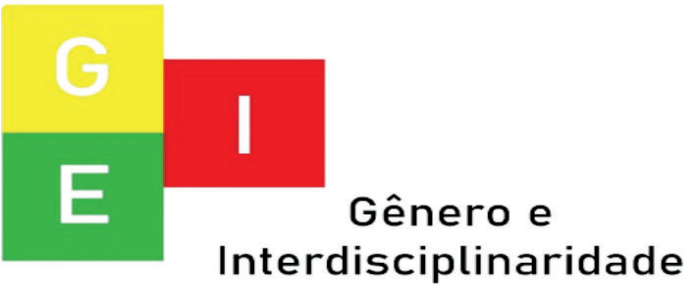


ISSN: 2675-7451

Vol. 02 - n 03 - ano 2021

Editora Acadêmica Periodicojs

da autonomia, fiscalização, julgamento, vigilância e energia”. Em 1891, a primeira Constituição da República trouxe em suas disposições gerais, artigo 89 a institucionalização definitiva do Tribunal de Contas da União, nos seguintes termos:

Art 89 - É instituído um Tribunal de Contas para liquidar as contas da receita $\mathrm{e}$ despesa e verificar a sua legalidade, antes de serem prestadas ao Congresso. Os membros deste Tribunal serão nomeados pelo Presidente da República com aprovação do Senado, e somente perderão os seus lugares por sentença (BRASIL, 1891).

E em 17 de janeiro de 1893, finalmente foi instalado o Tribunal de Contas da União (TCU), por meio do esforço "do então Ministro da Fazenda, Ser- zedello Corrêa, durante o Governo de Floriano Peixoto". Um fato histórico de suma relevância foi o primeiro caso em que o Tribunal de Contas declarou como ilegal uma

[...] nomeação feita pelo então Presidente Floriano Peixoto, de um parente do ex-Presidente Deodoro da Fonseca, o Presidente Floriano Peixoto achando injusto o ato do TCU, decretou a retirada da competência para impugnar despesas consideradas ilegais por ato da Presidência (LIMA, 2008, p. 14).

O então, Ministro da Fazendo Serzedello Corrêa, não concordando com o decreto presidencial pediu demissão do cargo, por meio de carta, onde explicava seu posicionamento, cujo fragmento tem o seguinte teor :

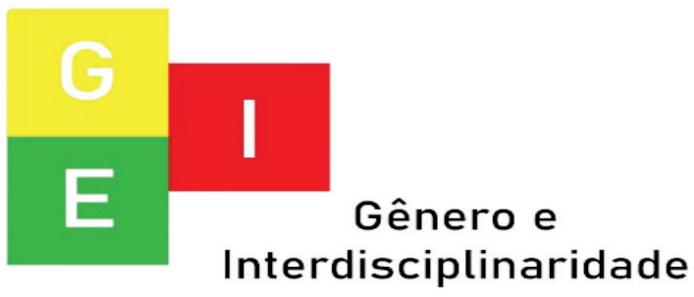


ISSN: 2675-7451

Vol. 02 - n 03 - ano 2021

Editora Acadêmica Periodicojs

Esses decretos anulam o Tribunal, o reduzem a simples Ministério da Fazenda, tiram-lhe toda a independência e autonomia, deturpam os fins da Instituição, e permitirão ao Governo a prática de todos os abusos e vós sabeis- é preciso antes de tudo, legislar para o futuro. Se a função do Tribunal no espírito da Constituição é apenas a de liquidar as contas e verificar a sua legalidade depois de feitas, o que eu contesto, eu vos declaro que esse Tribunal é mais um meio de aumentar o funcionalismo, de avolumar a despesa, sem vantagens para a moralidade da administração. Se, porém, ele é um Tribunal de exação como já o queria Alves Branco e como têm a Itália e a França, precisa- mos resignarmo-nos

a não gastar senão

o que for autorizado em lei e gastar sempre bem, pois para os casos urgentes a lei estabelece o recurso. Os governos nobilitam-se, Marechal, obedecendo a essa soberania suprema da lei e só dentro dela mantêm-se e são verdadeiramente independentes. Pelo que venho de expor, não posso, pois Marechal, concordar e menos referendar os decretos a que acima me refiro e por isso rogo vos digneis de conceder-me a exoneração do cargo de Ministro da Fazenda, indicando-me sucessor (LIMA, 2008, p. 14).

Com a promulgação da Constituição de 1934, foi criado no Capítulo VI os órgãos de cooperação nas atividades governa-

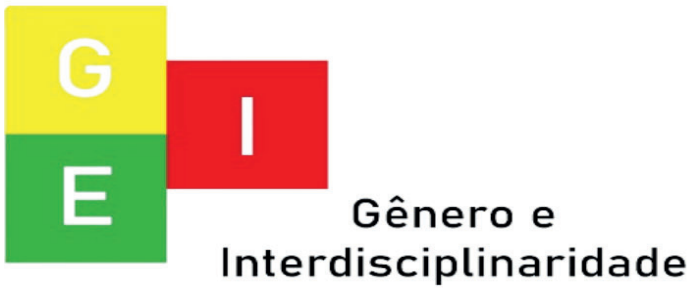


ISSN: 2675-7451

Vol. 02 - n 03 - ano 2021

Editora Acadêmica Periodicojs

mentais, na Seção II o Tribunal

de Contas, artigo 99-102, nos seguintes termos:

Art 99 - É mantido o Tribunal de Contas, que, diretamente, ou por delegações organizadas de acordo com a lei, acompanhará a execução orçamentária e julgará as contas dos responsáveis por dinheiros ou bens públicos.

Art 100 - Os Ministros do Tribunal de Contas serão nomeados pelo Presidente da República, com aprovação do Senado Federal, e terão as mesmas garantias dos Ministros da Corte Suprema.

Parágrafo único - $\mathrm{O}$ Tribunal de Contas terá, quanto à organização do seu Regimento Interno e da sua Secretaria, as mesmas atribuições dos Tribunais Judiciários.

Art 101 - Os contra- tos que, por qualquer

modo, interessarem imediatamente à receita ou à despesa, só se reputarão perfeitos e acabados, quando registrados pelo Tribunal de Contas. A recusa do registro suspende a execução do contrato até ao pronunciamento do Poder Legislativo. $\S 1^{\circ}$ - Será sujeito ao registro prévio do Tribunal de Contas qualquer ato de Administração Pública, de que resulte obrigação de pagamento pelo Tesouro Nacional, ou por conta deste. $\S 2^{\circ}-$ Em todos os casos, a recusa do registro, por falta de saldo no crédito ou por imputação a crédito impróprio, tem caráter proibitivo; quando a recusa tiver outro fundamento, a despesa poderá efetuar-se após despa-

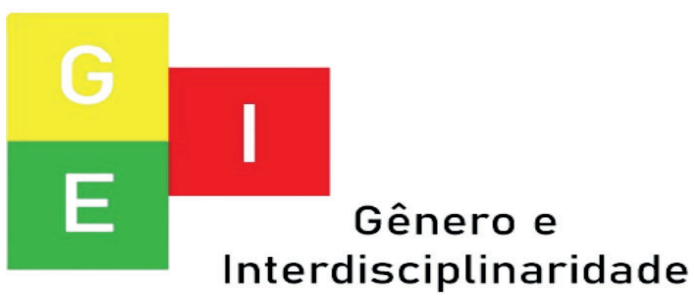


ISSN: 2675-7451

Vol. 02 - n 03 - ano 2021

Editora Acadêmica Periodicojs

cho do Presidente da República, registro sob reserva do Tribunal de Contas e recurso ex officio para a Câmara dos Deputados.

$\S 3^{\circ}$ - A fiscalização financeira dos serviços autônomos será feita pela forma prevista nas leis que os estabelecerem.

Art 102 - O Tribunal de Contas dará parecer prévio, no prazo de trinta dias, sobre as contas que o Presidente da República deve anualmente prestar à Câmara dos Deputados. Se estas não lhe forem enviadas em tempo útil, comunicará o fato à Câmara dos Deputados, para os fins de direito, apresentando-lhe, num ou noutro caso, minucioso relatório do exercício financeiro terminado (BRASIL, 1934, p. 72).

A Constituição de 1937 não apresentou mudanças sobre as atribuições do TCU determinados na Carta Magna anterior, apenas acrescentou "parecer prévio das contas do Presidente da República". Na Constituição de 1946 trouxe no artigo 22 o seguinte texto:

Art 22 - A administração financeira, especialmente a execução do orçamento, será fiscalizada na União pelo Congresso Nacional, com o auxílio do Tribunal de Contas, e nos Estados e Municípios pela forma que for estabelecida nas Constituições estaduais (BRASIL, 1946, p.18).

A Constituição de 1967, ratificada pela Emenda Constitucional $\mathrm{n}^{\circ}$, de 1969 , determina no artigo 70 sobre a fiscalização fi-

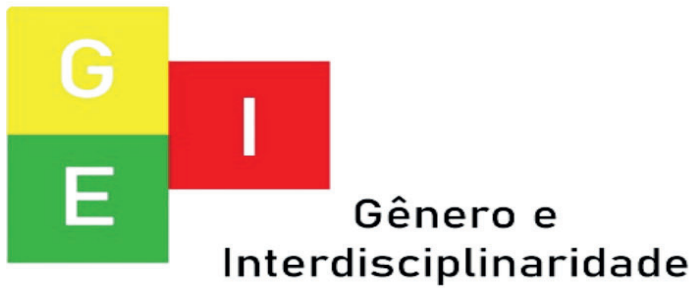


ISSN: 2675-7451

Vol. 02 - n 03 - ano 2021

Editora Acadêmica Periodicojs

nanceira e orçamentária do TCU, enfatizando sua competência para apreciação da legalidade das contas públicas. Dando ao TCU uma nova atribuição, que foi exercer auditoria financeira e orçamentária sobre contas das unidades dos três poderes do Estado, dessa forma ficando criado os sistemas de controle externo com o objetivo de controlar as contas públicas externas. Os termos do artigo 70 são os seguintes:

Art. 70. A fiscalização financeira e orçamentária da União será exercida pelo Congresso Nacional mediante controle externo e pelos sistemas de controle interno do Poder Executivo, instituídos por lei.

$\S 1^{\circ} \mathrm{O}$ controle externo do Congresso Nacional será exercido com o auxílio do Tribunal de Contas da União e compre- enderá a apreciação das contas do Presidente da República, o desempenho das funções de auditoria financeira e orçamentária, bem como o julgamento das contas dos administradores e demais responsáveis por bens e valores públicos.

$\S 2^{\circ}$ O Tribunal de Contas da União dará parecer prévio, em sessenta dias, sobre as contas que o Presidente da República prestar anualmente; não sendo estas enviadas dentro do prazo, o fato será comunicado ao Congresso Nacional, para os fins de direito, devendo aquele Tribunal, em qualquer caso, apresentar minucioso relatório do exercício financeiro encerrado. $\S 3^{\circ}$ A auditoria financeira e orçamentária será exercida

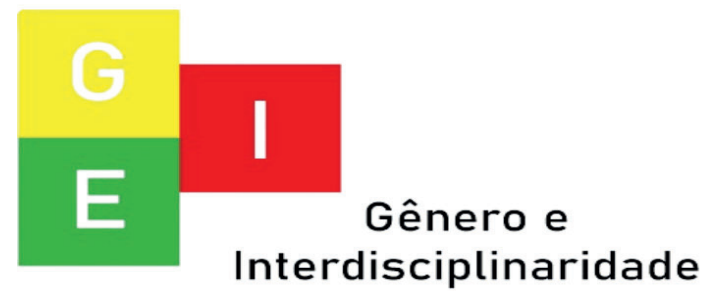


Vol. 02 - n 03 - ano 2021

Editora Acadêmica Periodicojs

sobre as contas das unidades administrativas dos três Poderes da União, que, para esse fim, deverão remeter demonstrações contábeis ao Tribunal de Contas da União, a que caberá realizar as inspeções necessárias.

$\S 4^{\circ} \mathrm{O}$ julgamento da regularidade das contas dos administradores e demais responsáveis será baseado em levantamento contábeis, certificados de auditoria e pronunciamento das autoridades administrativas, sem prejuízo das inspeções mencionadas no parágrafo anterior. $\S 5^{\circ}$ As normas de fiscalização financeira e orçamentária estabelecidas nesta seção aplicar-se-ão às autarquias (BRASIL, 1967, p. 68).

E foi com a edição da
Constituição Federal de 1988, que o Tribunal de Contas passou “a ter sua jurisdição e competências próprias e ampliadas, recebendo poderes para auxiliar o Congresso Nacional, exercendo a fiscalização contábil, financeira, orçamentária, operacional e patrimonial do Estado Brasileiro" (BRASIL, 1988, p. 71).

A estrutura organizacional do TCU compreende o colegiado e plenário ( $1^{\circ}$ e $2^{\circ}$ câmara, comissão de regimento e comissão de jurisprudência), autoridades (ministros, ministros substitutos, ministério público, vice presidência, corregedoria e presidência), secretarias gerais dos gabinetes e secretarias gerais de controle externo, núcleo de controle externo (adgecex, segecex), cogep, copin e coinfra (TCU, 2020). A seguir teremos o entendimento detalhado das funções do Tribunal de Contas.

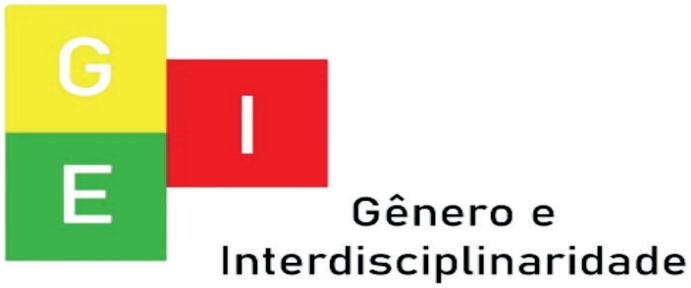


Vol. 02 - n 03 - ano 2021

Editora Acadêmica Periodicojs

ATUAÇÃO E COMPOSIÇÃO

DO TRIBUNAL DE CONTAS

DA UNIÃO

As áreas de atuação do

Tribunal de Contas da União são a administração do Estado; agricultura e organização agrária (neste setor o TCU monitora ações governamentais sobre mudanças climáticas, verifica os avanços dos beneficiários de reforma agrária entre outras funções); Ciências, tecnologia e inovação; desenvolvimento; meio ambiente; rodovias; turismo; agricultura e organização agrária; comunicação; educação; indústria, serviços e comércio exterior; petróleo e mineração; saúde; assistência social; cultura; energia elétrica; infraestrutura hídrica, portos e hidrovias; previdência social; segurança pública; aviação civil; defesa nacional; esporte; infraestrutura urbana e mobilidades; relações exteriores; trabalho e emprego. As áreas transversais de atuação do TCU são: combate à corrupção, contratações públicas, finanças públicas, fiscobras, pessoal, sistema financeiro nacional, tecnologia da informação, transferências obrigatórias, eficiências e produtividades, análises de políticas públicas (TCU, 2020).

É visível a abrangência de atuação do TCU, na fiscalização, análise e julgamento das contas da administração pública assim como de todos os responsáveis pelo erário público, conforme estabelece o artigo $71 \mathrm{da}$ Carta Magna de 1988:

Art. 71. O controle externo, a cargo do Congresso Nacional, será exercido com o auxílio do Tribunal de Contas da União, ao qual compete:

I - apreciar as

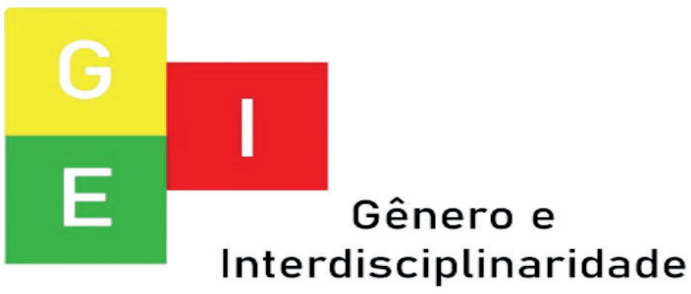


ISSN: 2675-7451

Vol. 02 - n 03 - ano 2021

Editora Acadêmica Periodicojs

contas prestadas

anualmente pelo

Presidente da Repú-

blica, mediante pare-

cer prévio que deverá

ser elaborado em ses-

senta dias a contar de

seu recebimento;

II - julgar as contas

dos administradores

e demais responsáveis por dinheiros, bens e valores públi$\cos$ da administração direta e indireta, incluídas as fundações e sociedades instituídas e mantidas pelo Poder Público federal, e as contas daqueles que derem causa a perda, extravio ou outra irregularidade de que resulte prejuízo ao erário público;

III - apreciar, para fins de registro, a legalidade dos atos de admissão de pessoal, a qualquer título, na administração direta e indireta, incluídas as fundações institu- ídas e mantidas pelo Poder Público, excetuadas as nomeações para cargo de provimento em comissão, bem como a das concessões de aposentadorias, reformas e pensões, ressalvadas as melhorias posteriores que não alterem $\mathrm{o}$ fundamento legal do ato concessório;

IV - realizar, por iniciativa própria, da Câmara dos Deputados, do Senado Federal, de Comissão técnica ou de inquérito, inspeções e auditorias de natureza contábil, financeira, orçamentária, operacional e patrimonial, nas unidades administrativas dos Poderes Legislativo, Executivo e Judiciário, e demais entidades referidas no inciso II; V - fiscalizar as contas nacionais das empresas supranacio-

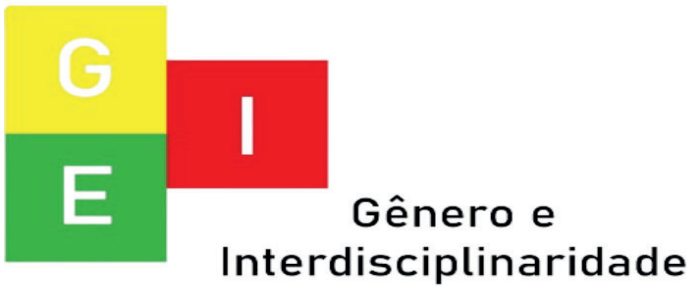


ISSN: 2675-7451

Vol. 02 - n 03 - ano 2021

Editora Acadêmica Periodicojs

nais de cujo capital

social a União participe, de forma direta ou indireta, nos termos do tratado constitutivo;

VI - fiscalizar a aplicação de quaisquer recursos repassados pela União mediante convênio, acordo, ajuste ou outros instrumentos congêneres, a Estado, ao Distrito Federal ou a Município;

VII - prestar as informações solicitadas pelo Congresso Nacional, por qualquer de suas Casas, ou por qualquer das respectivas Comissões, sobre a fiscalização contábil, financeira, orçamentária, operacional e patrimonial e sobre resultados de auditorias e inspeções realizadas;

VIII - aplicar aos responsáveis, em caso de ilegalidade de despesa ou irregularidade de contas, as sanções previstas em lei, que estabelecerá, entre outras cominações, multa proporcional ao dano causado ao erário;

IX - assinar prazo para que o órgão ou entidade adote as providências necessárias ao exato cumprimento da lei, se verificada ilegalidade;

X - sustar, se não atendido, a execução do ato impugnado, comunicando a decisão à Câmara dos Deputados e ao Senado Federal;

XI - representar ao Poder competente sobre irregularidades ou abusos apurados. $\S 1^{\circ}$ No caso de contrato, o ato de sustação será adotado diretamente pelo Congresso Nacional, que solicitará, de imediato, ao Poder

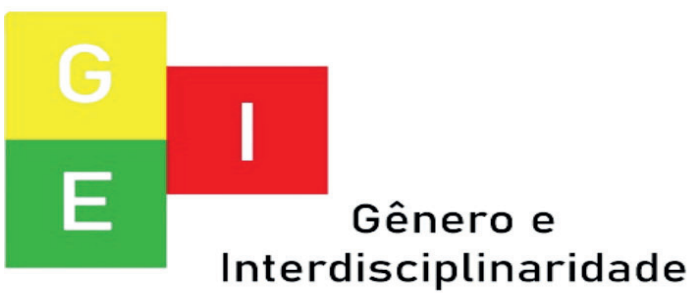


ISSN: 2675-7451

Vol. 02 - n 03 - ano 2021

Editora Acadêmica Periodicojs

Executivo as medi- sos: seis são indicados pelo Condas cabíveis.

$\S 2^{\circ} \mathrm{Se}$ o Congresso

Nacional ou o Poder

Executivo, no prazo

de noventa dias, não

efetivar as medidas

previstas no parágra-

fo anterior, o Tribu-

nal decidirá a respeito.

$\S 3^{\circ}$ As decisões do

Tribunal de que re-

sulte imputação de

débito ou multa terão

eficácia de título executivo.

$\S 4^{\circ} \mathrm{O}$ Tribunal encaminhará ao Congresso Nacional, trimestral e anualmente, relatório de suas atividades.

Portanto, os nove ministros que compõem a estrutura do TCU possuem as mesmas prerrogativas, garantias, vencimentos e impedimentos dos ministros dos ministros do STJ. A escolha dos ministros segue os seguintes pasgresso Nacional, um pelo é indicação do presidente da República e dois são indicação de auditores e membros do Ministério Público. Ainda faz parte da composição do TCU um procurador-geral, três subprocuradores-gerais e quatro procuradores, que são nomeados pelo presidente da República, a exigência é que sejam concursados e com título de bacharel em Direito.

Sendo um órgão colegiado está diretamente ligado a outros órgãos da administração pública. Suas deliberações são tomadas em plenário, sendo essa a instância máxima do TCU, quando os casos podem ser deliberados em Câmaras as decisões são deliberadas em sessões plenárias de uma dessas Câmaras, sempre com a presença do representante do Ministério Público ligados ao TCU. Esse órgão é autônomo,

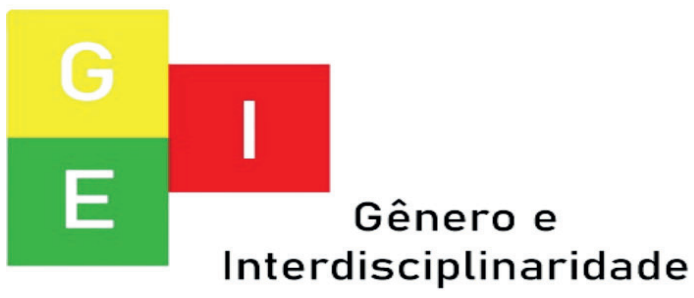


Vol. 02 - n 03 - ano 2021

Editora Acadêmica Periodicojs

tendo como missão promover a defesa da ordem jurídica.

O TCU tem como fundamento institucional apoiar tecnicamente a prática de cuidado, atenção e vigilância dos bens e patrimônios do Estado, dentro dos parâmetros jurisdicionais de suas competências conforme estabelece a Constituição Federal de 1988 , e as leis infraconstitucionais, assim como as jurisprudências que forem determinadas por suas secretarias. Estas secretarias estão sob ordens de unidades técnico-executivas com sede em Brasília e nos estados da federação. O papel das secretarias estaduais é fiscalizar a aplicação de verbas federais que são repassadas aos estados e municípios, por meio de convênios e outros mecanismos legais. Assim cabe ao TCU as seguintes funções: fiscalizar, consultar, informar, judicar, sancionar, corrigir, norma- tizar e ouvir, educar e orientar. A seguir destaca-se as funções do TCU.

\section{Funções do Tribunal de Contas da União}

As funções do Tribunal de Contas da União compreendem fiscalizar, consultar, informar, judicar, sancionar, corrigir, normatizar e ouvir, educar e orientar. A seguir apresenta-se cada uma dessas funções.

Função Fiscalizadora

- na função fiscalizadora o TCU realiza auditorias e inspeções, a partir de denúncias em órgãos e instituições federais ou em programas governamentais, que tanto ocorre por iniciativa própria, assim como por requerimento do Congresso Nacional, com objetivo de analisar a legalidade de atos públicos. A atuação fiscalizadora compreende destinação

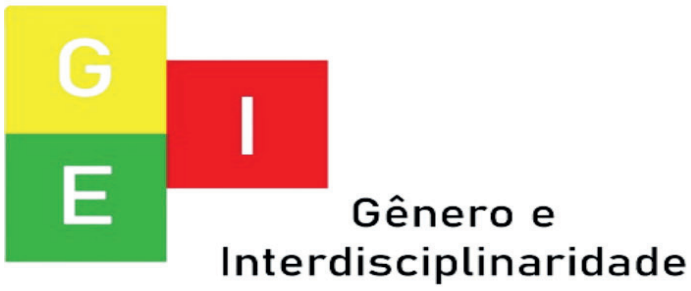


ISSN: 2675-7451

Vol. 02 - n 03 - ano 2021

Editora Acadêmica Periodicojs

de recursos humanos e materiais, com propósito de analisar se a gerência dos bens públicos está sendo realizado dentro de legalidade (ZAMPARETTI, 2009). A fiscalização dos recursos públicos é realizada em cinco etapas que são:

1) Levantamento: é o instrumento com o qual o TCU utiliza para compreender o funcionamento do órgão ou entidade pública, descobrindo os meandros da sua organização, identificando os objetos e instrumentos a serem fiscalizados, avaliando as suas viabilidades de realização;

2) Auditoria: é o instrumento que permite a verificação no local, da legalidade e legitimidade dos atos de gestão, tanto em seu aspecto contábil, quanto em suas características financeiras, orçamentárias e patrimoniais, bem como os possíveis resultados que poderão ser alcançados pelo órgão, ente público, projetos e programas;

3) Inspeção: cumpre à obtenção de informações não disponíveis no Tribunal, quanto para esclarecer dúvidas acerca dos procedimentos, apura fatos trazidos ao Tribunal por meio de representações ou denúncias;

4) Acompanhamento: visa monitorar e avaliar a gestão de órgãos, entidades ou programas do governo em período de tempo estimado;

5) Monitoramento: é o instrumento utilizado para aferir o cumprimento das deliberações proferidas pelo Tribunal e seus resultados (BARRETO, 2016, p.5).

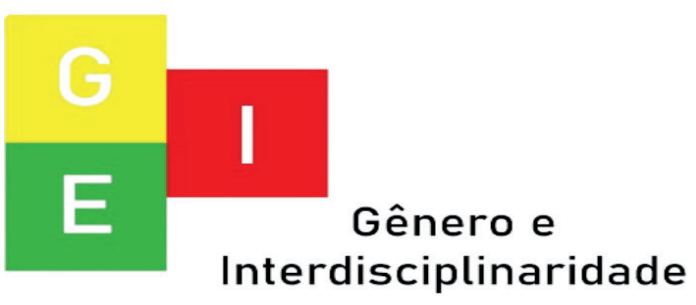


ISSN: 2675-7451

Vol. 02 - n 03 - ano 2021

Editora Acadêmica Periodicojs

Portanto, a função fisca-

lizadora inicia com levantamento dos dados que compreende a fiscalização, depois vem a auditoria que vai identificar a legalidade ou não dos atos dos agentes públicos, a inspeção é a apuração dos fatos, o acompanhamento é o momento de monitorar a gestão publicas das instituições e o monitoramento é averiguação do cumprimento ou não das deliberações do TCU ao órgão fiscalizado.

Função Consultiva - a consultoria é exercida por meio de produção de pareceres técnicos antecipados e particulares, do balanço anual das contas lançadas pelos representantes dos Poderes Executivo, Legislativo e Judiciário, como também dos representantes do Ministério Público da União. No caso de julgamento que será realizado pelo Congresso Nacional, cabe ao TCU prestar consultoria no exame das contas realizadas pelas autoridades, esclarecendo dúvidas sobre à aplicação dos institutos legais e regulamentos sobre as matérias de competência do órgão fiscalizador (RODRIGUES, 2009).

\section{Função Informativa -}

a prestação de informação pelo TCU ao Congresso Nacional é uma função importante que deve atingir todas as realizações fiscalizadores exercidas pelo órgão, assim como é dever do TCU informar os resultados de inspeções e auditorias realizadas, compreendendo relatórios que devem ser enviados aos representantes do poder competente que vai julgar as irregularidades ou apuração de abusos, também é de função do TCU informar por meio de relatórios todas as atividades exercidas pelo Tribunal ao Congresso Nacional (PORTAL/

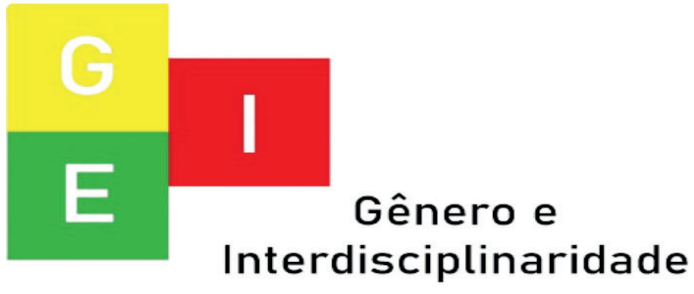


ISSN: 2675-7451

Vol. 02 - n 03 - ano 2021

Editora Acadêmica Periodicojs

TCU, 2020).

Função Judicante os julgamentos realizados pelo TCU compreendem a análise de contas que envolvem os administradores públicos, assim como de todos os "responsáveis por dinheiro, bens, valores públicos da administração direta e indireta". Por meio de processo administrativo o TCU julga as prestações de contas, cabendo aos ministros ou auditores do TCU relatar, votar e submeter proposta de acórdão, diante da análise e instrução preliminar realizada por órgãos técnicos da Secretaria do Órgão. Os Tribunais de Contas têm autorização para realizar anualmente o julgamento das contas dos administradores e responsáveis pelos bens públicos (BARRETO, 2016).

Função Sancionadora - o TCU tem como função sancionar e aplicar as sanções previstas na Lei Orgânica do Tribunal, conforme a Lei $n^{\circ} 8.443$, de 16 de julho de 1992, quando são apuradas irregularidades ou ilegalidade nas despesas ou contas. A função sancionadora do TCU está preconizado no artigo 71 da Constituição Federal de 1988, nos incisos VIII a XI, conforme já descrito anteriormente, aplicando as penalidades cabíveis (PORTAL/TCU, 2020).

\section{Função Corretiva -}

diante da comprovação de ilegalidade ou irregularidade em atos de administradores públicos, o Tribunal de Contas oferece um prazo para que corrijam o erro e cumpram a lei. Se não atendida as determinações para o cumprimento da Lei, cabe ao TCU promover a sua função corretiva, ou seja, aplicar sanções cabíveis ao ato não atendido, e, diante da ilegalidade de contas e despesas apresentadas pelos órgãos gover-

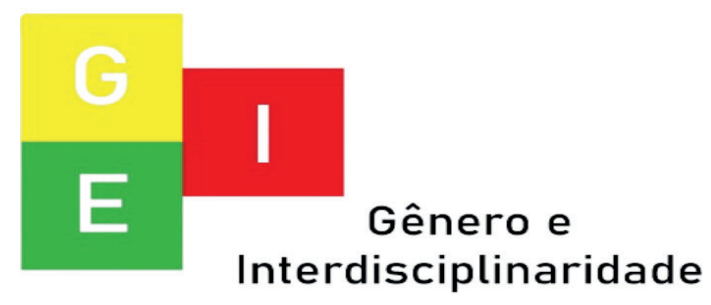


ISSN: 2675-7451

Vol. 02 - n 03 - ano 2021

Editora Acadêmica Periodicojs

namentais (LIMA, 2007).

\section{Funções Normativas}

- essa função está determinada

na Lei Orgânica, autorizando o

TCU quando necessário expedir instruções e atos normativos, que são obrigatórios, cabendo aos infratores responderem civilmente pelos seus atos (LIMA, 2007).

\section{Função de Ouvidoria}

- a ouvidoria por meio do Tribunal de Contas compreende "em receber denúncias e representações relativas a irregularidade ou ilegalidade que lhe sejam comunicadas pelos responsáveis pelo controle interno, por autoridades, cidadãos, partidos políticos, associações e sindicatos" (BARRETO, 2016, p.7). A ouvidoria pelo TCU faz cumprir o que determina o parágrafo $2^{\circ}$ do artigo $74 \mathrm{da}$ Constituição Federal de 1988 “ $2^{\circ}$ Qualquer cidadão, partido político, associação ou sindicato é parte legítima para, na forma da lei, denunciar irregularidades ou ilegalidades perante o Tribunal de Contas da União", assim como o parágrafo $3^{\circ}$ do artigo 53 da Lei $n^{\circ} 8.443 / 1992$ :

Art. 53. Qualquer cidadão, partido político, associação ou sindicato é parte legítima para denunciar irregularidades ou ilegalidades perante o Tribunal de Contas da União. $\S 3^{\circ} \mathrm{A}$ denúncia será apurada em caráter sigiloso, até que se comprove a sua procedência, e somente poderá ser arquivada após efetuadas as diligências pertinentes, mediante despacho fundamentado do responsável.

Dessa forma, atendendo aos preceitos legais o TCU após ouvir e examinar as denúncias determina a recepção e a apuração dos fatos, quando não atende aos requisitos legais e regimen-

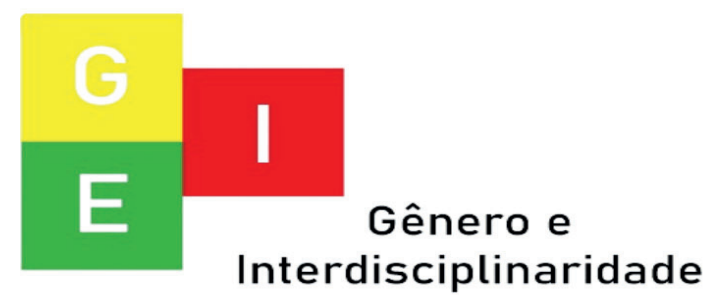


ISSN: 2675-7451

Vol. 02 - n 03 - ano 2021

Editora Acadêmica Periodicojs

tais, a denúncia é arquivada.

Ainda, a Súmula $n^{\circ} 347$ do ETF amplia a função do TCU em "exercício de suas atribuições, pode apreciar a constitucionalidade das leis e dos atos do Poder Público", saindo assim do âmbito orçamentário, financeiro, contábil, operacional e patrimonial.

ATUAÇÃO JURISDICIONAL DO TRIBUNAL DE CONTAS

Segundo Fernandes (1999, p. 187) os limites de atuação do controle externo por meio dos tribunais de contas devem levar em conta os ensinamentos de Montesquieu em "O Espírito das Leis" "para que não possa abusar do poder (...), é preciso que, pelas disposições das forças, o poder detenha o poder". Ainda Fernandes (1999, p. 187) cita Calheiros Bonfim, que filosoficamente de- clara que "Todo o poder a salvo de controle externo tende ao abuso, ao arbítrio, ao autoritarismo. Dessa regra não se excetua o Judiciário, nem qualquer outra instituição".

Constata-se que tanto na visão de Montesquieu como de Calheiros Bomfim o poder quando não controlado pode levar ao abuso e autoritarismo, porém $\mathrm{Ca}$ lheiros Bomfim fala em exceção ao controle externo, o que deixa o entendimento de que o Tribunal de Contas é um poder exercido para limitar outros poderes, mencionando que até o Judiciário deve ser controlado externamente.

Fazendo uma análise do artigo 71 da Constituição Federal de 1988, percebe-se que o dispositivo apresenta a primeira limitação do TCU, que é de auxiliar o Congresso Nacional no controle externo, ou seja a competência

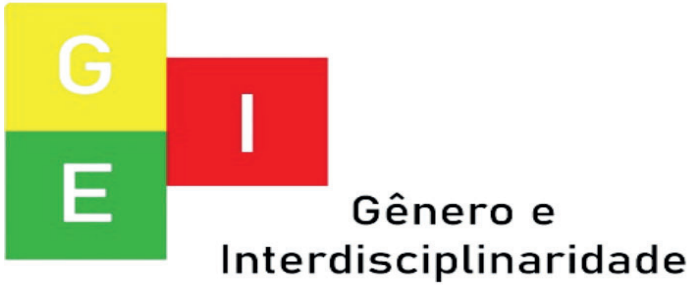


ISSN: 2675-7451

Vol. 02 - n 03 - ano 2021

Editora Acadêmica Periodicojs

do controle é do Congresso Na- lativa".

cional, cabendo ao TCU auxili-

De acordo com Silva

á-lo com pareceres técnicos das

contas prestadas pelos agentes

públicos.

No caso das contas prestadas pelo Presidente da República, verifica-se a limitação jurisdicional do TCU. Pois essa é função exclusiva do Congresso Nacional, conforme preconiza o artigo 49, inciso IX “Art. 49. É da competência exclusiva do Congresso Nacional: (...) IX - julgar anualmente as contas prestadas pelo Presidente da República e apreciar os relatórios sobre a execução dos planos de governo", assim como o artigo 51, inciso II: “ Art. 51. Compete privativamente à Câmara dos Deputados: (...) II proceder à tomada de contas do Presidente da República, quando não apresentadas ao Congresso Nacional dentro de sessenta dias após a abertura da sessão legis-

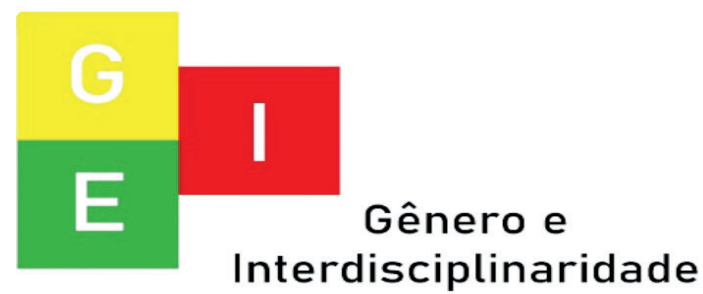

g) os que tiverem suas contas relativas ao exercício de cargos ou funções públicas rejeitadas por irregularidade insanável que configure ato doloso de improbidade administrativa, e por decisão irrecorrível do órgão competente, salvo se esta houver sido suspensa ou anulada pelo Poder Judiciário, para as eleições que se realizarem nos 8 (oito) anos seguintes, contados a partir da data da decisão, aplicando-se o disposto no inciso II do art. 71 da Constituição Federal, a todos 
ISSN: 2675-7451

Vol. 02 - n 03 - ano 2021

Editora Acadêmica Periodicojs

os ordenadores de despesa, sem exclusão de mandatários que houverem agido nessa condição;

O que se vê na alínea "g" do art. $1^{\circ}$, é que o legislador não separou "as contas de governo e as contas de gestão", ainda dispõe sobre "ato doloso de improbidade administrativa", sendo que o julgamento de atos dolosos de improbidade administrativa é de competência da justiça eleitoral. Pois a competência do Tribunal de Contas é analisar e julgar atos financeiros, contábeis e orçamentários (SILVA, 2016).

Ainda, se percebe uma clara violação de preceito constitucional na alínea "g" do artigo $1^{\circ}$ da Lei Complementar $n^{\circ}$ 135/2010, conforme destaca Silva (2016, p.156):

[...] viola-se o princípio do contraditório e da ampla defesa, pois suprime do ordenador de despesa a possibilidade de exercer sua defesa na Corte de Contas no que tange ao dolo, que sequer é mencionado nas decisões, e consequentemente do ato de improbidade administrativa. Portanto, para aplicação do disposto na alínea "g", deve-se observar e respeitar alguns requisitos objetivos, a saber: (I) se houve rejeição de contas (contudo quem julga é o poder Legislativo); (II) se a decisão é definitiva; (III) se realmente a irregularidade é insanável; e (IV) se desta irregularidade foi verificado ato doloso de improbidade administrativa (Tribunal de Contas não possui competência para apreciar e julgar ato doloso de improbidade ad-

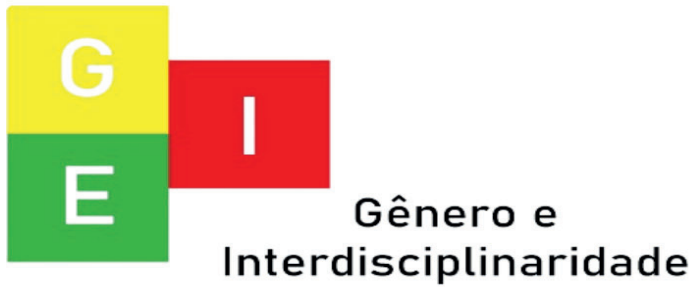


ISSN: 2675-7451

Vol. 02 - n 03 - ano 2021

Editora Acadêmica Periodicojs

ministrativa). Porém, as verificações destes requisitos não são de competência dos Tribunais de Contas, ou seja, nas suas decisões não se verifica o preenchimento dos requisitos necessários para que seja declarada a inelegibilidade do ordenador de despesa, mesmo que a inelegibilidade seja decidida pela justiça eleitoral. E com isso percebe-se que a lei infraconstitucional deu atribuição aos Tribunais de Contas sem dar a competência.

Percebe-se que o limite jurisdicional dos Tribunais de Contas deve seguir o que estabelece o artigo 71 da Constituição Federal de 1988, ou seja:

[...] apreciar e emitir parecer prévio no que tange às contas de governo; apreciar e julgar as contas de gestão dos ordenadores de despesa com responsabilidade de receber e gerenciar recursos públicos; bem como apreciar a legalidade dos atos de admissão de pessoal, excetuadas as nomeações para cargo de provimento em comissão; realizar inspeções e auditorias de natureza contábil, financeira, orçamentária, operacional e patrimonial nas unidades administrativas dos Poderes Legislativos, Executivo e Judiciário e demais entidades; além de fiscalizar a aplicação de quaisquer recursos repassados mediante convênio, acordo, ajuste ou outros instrumentos congêneres (SILVA, 2016, p. 158).

Nesse sentido Meirelles

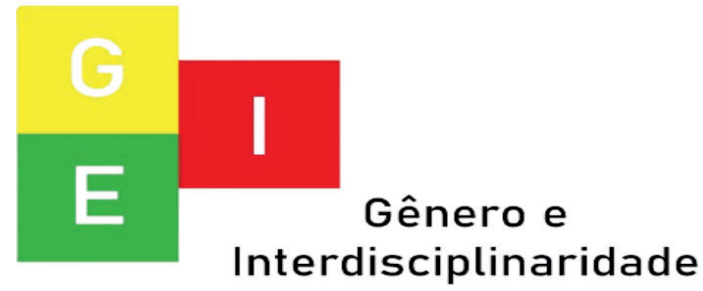


ISSN: 2675-7451

Vol. 02 - n 03 - ano 2021

Editora Acadêmica Periodicojs

(1994, p. 108 Apud SILVA, 2016,

p. 160) destaca:

Quanto aos Tribunais de Contas do Estado e dos Municípios que os tiverem, bem como os órgãos de contas municipais previstos na Constituição da República (art. 31, § $1^{\circ}$ ), como dispõem apenas de funções opinativas sobre as contas que lhes são apresentadas, não nos parece que possam pedir a intervenção do Estado no Município sem que tais contas estejam apreciadas pela Câmara Municipal, que é o órgão julgador competente. Sua missão constitucional é unicamente a de emitir parecer prévio sobre essas contas, apontando as irregularidades e indicando as medidas corretivas, inclusive a intervenção no Município, para que a Câmara Municipal julgue com pleno conhecimento da matéria. A decisão é da Câmara de Vereadores, à qual caberá aplicar as sanções de sua alçada (rejeição das contas e cassação do mandato do Prefeito e solicitar aos órgãos estaduais competentes as providências complementares cabíveis, dentre as quais a intervenção no Município e o processo criminal contra o Prefeito). Assim ficará preservada a autonomia municipal, e assegurada a probidade administrativa do governo local.

O que se constata a partir dos eventos citados acima é que os limites de atuação dos Tribunais de Contas são os previstos no artigo 71 da Carta Magna, o que estiver fora desses limites é

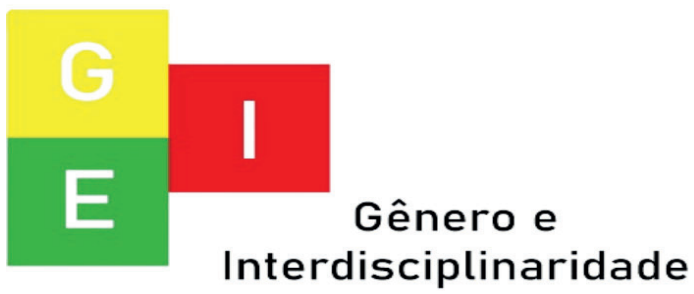


ISSN: 2675-7451

Vol. 02 - n 03 - ano 2021

Editora Acadêmica Periodicojs

usurpação de jurisdição e poder.

Nesse sentido, os limi-

tes do Tribunal de Contas estsão

CONTROLE JUDICIAL DAS

DECISÕES DOS TRIBUNAIS DE CONTAS

Existe entendimento comum entre a doutrina e jurisprudência de que as decisões dos Tribunais de Contas são meramente administrativas, isso mostra que não produzem "coisa julgada judicial”, porque não é um órgão que integra o Poder Judiciário, que é o único poder que tem a jurisdição de julgamento.

De acordo com Di Pietro (2003, p. 639) “a função de julgar as contas não se trata de função jurisdicional, porque o Tribunal de Contas apenas examina as contas, tecnicamente, e não aprecia a responsabilidade do agente público, que é de competência exclusiva do Poder Judiciário." dentro da jurisdição administrativa, sendo que os processos podem ser enviados as instâncias do Poder Judiciário, que poderá acatar ou não a decisão do Tribunal de Contas. Essa limitação do órgão vai de encontro ao princípio da inafastabilidade da tutela jurisdicional, preconizado no inciso $\mathrm{XXXV}$ do artigo $5^{\circ}$ da Constituição Federal de 1988, com o seguinte texto "a lei não excluirá da apreciação do Poder Judiciário lesão ou ameaça a direito".

Assim como as decisões julgadas pelo Tribunal de Contas com base em princípios como o da proporcionalidade, moralidade, eficiência e na Teoria dos Motivos Determinantes. Nesse sentido inúmeras discussões doutrinárias e jurisprudenciais aparecem no sentido de averiguar

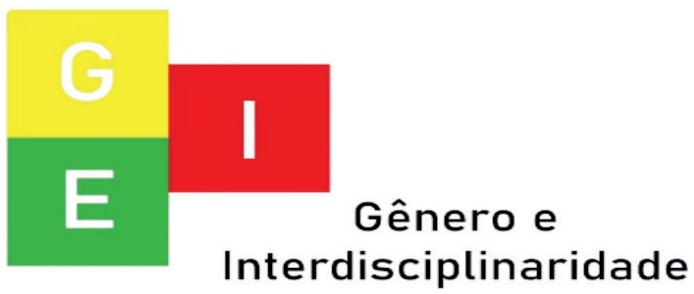


ISSN: 2675-7451

Vol. 02 - n 03 - ano 2021

Editora Acadêmica Periodicojs

os limites da atuação do Poder

Judiciário na apreciação de julgamentos feitos pelo Tribunal de Contas (LOPES FILHO, 2012).

O Supremo Tribunal

Federal tinha pacíficado entendimento jurisprudencial de que o Judiciário só tinha influência para rever aspectos formais das decisões dos Tribunais de Contas, conforme pode ser visto no julgado de 31 de dezembro de 1969 em que o Ministro Henrique D'Avila foi relator:

Ao apurar o alcance dos responsáveis pelo dinheiro público, o Tribunal de Contas pratica ato insusceptível de revisão na via judicial a não ser quanto ao seu aspecto formal ou tisna de ilegalidade manifesta. Mandado de segurança não conhecido (STF. Mandado de Segurança (MS) $\mathrm{n}^{\circ}$ 7.280. Relator: Min. Henrique
D'Avila, julgamento 31 de dezembro de 1969).

Segundo Lopes Filho (2012), embora antigo esse entendimento jurisprudencial continuou sendo usado por alguns tribunais, como o ocorrido em 3 de dezembro de 2002, pela Terceira Turma do Tribunal Regional da $4^{0}$ Região, na ação de improbidade administrativa julgada pelo Tribunal de Contas da União, onde o TRF 4 considerou que:

Ademais, a Eg. Corte de Contas, acolhendo o pronunciamento do Parquet junto àquele Tribunal, afastou o caráter ilícito de grande parte dos fatos noticiados na peça vestibular, o que, na jurisprudência do Supremo Tribunal Federal e do Superior Tribunal de Justiça, impede o seu reexame na via judi-

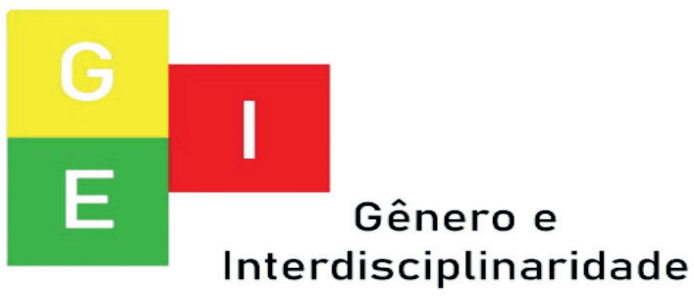


ISSN: 2675-7451

Vol. 02 - n 03 - ano 2021

Editora Acadêmica Periodicojs

cial, a não ser quanto ao seu aspecto formal ou tisna de ilegalidade manifesta (Tribunal Regional Federal da $4^{\text {a }}$ Região TRF-4 - Agravo De Instrumento: AG 19240 SC 2002.04.01.0192400 , julgado em 3 de dezembro de 2002).

Porém, levando em considerações o princípio da inafastabilidade da tutela jurisdicional, previsto no inciso XXXV do artigo $5^{\circ}$ da Constituição Federal de 1988, já destacado anteriormente, em que preconiza que "a lei não excluirá da apreciação do Poder Judiciário lesão ou ameaça a direito", a jurisprudência recente, vem inteferindo em julgados do Tribunal de Contas, como é o caso do julgado em 2007 pela Primeira Turma do TRF da $5^{\circ} \mathrm{Re}-$ gião, em que o Município de Cachoeirinha (PE) interpôs recurso de apelação contra a sentença do Tribunal de Contas da União. O TRF 5 destacou na Ementa que a competência do Judiciário cabe controlar as decisões do TCU, como pode ser visto no trecho a seguir:

As decisões dos Tribunais de Contas podem ser objeto de controle judicial não apenas quanto à formalidade de que se revestem, mas inclusive quanto a sua legalidade, considerando-se que tais decisões não fazem coisa julgada, que é qualidade exclusiva das decisões judiciais como decorrência da unicidade de jurisdição de nosso sistema constitucional. Não há como eximir as decisões dos Tribunais de Contas da sindicabilidade judicial, quando a Constituição Federal impõe a inafastabilidade do

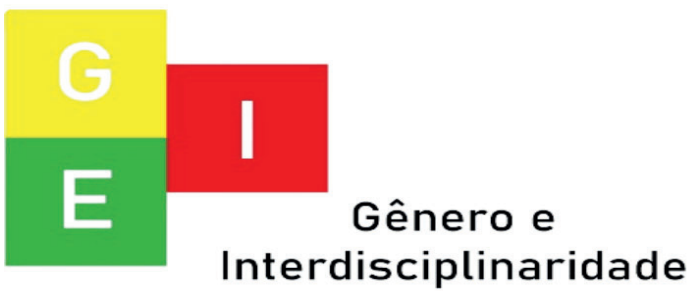


ISSN: 2675-7451

Vol. 02 - n 03 - ano 2021

Editora Acadêmica Periodicojs

controle judicial de qualquer lesão ou ameaça de lesão a direito, como princípio (TRF5 - Apelação Civel: AC 380126 PE 2005.83.02.0004318.

Relator(a): Desembargador Federal Élio Wanderley de Siqueira Filho (Substituto). Órgão Julgador: Primeira Turma. Julgamento: 11/07/2007)

Mais recentemente, o Supremo Tribunal Federal interferiu em decisão julgada pelo Tribunal de Contas, como é o caso da previsão do Decreto $\mathrm{n}^{\mathrm{o}}$ 2.745/1998 que aprova o Regulamento do Procedimento Licitatório Simplificado da Petróleo Brasileiro S.A. - PETROBRÁS previsto no artigo 67 da Lei $n^{\circ}$ 9.478, de 6 de agosto de 1997. O Tribunal de Contas da União não aceita esse tipo de procedimento, exigindo que a licitação da Petrobrás seja realizada de acordo com a Lei $n^{\circ} 8.666 / 1993$.

No entanto:

[...] Em análise ao Mandado de Segurança (MS) 28745, a ministra Ellen Gracie, do Supremo Tribunal Federal (STF), deferiu pedido de liminar feito pela Petrobras contra decisão do Tribunal de Contas da União (TCU) que determinou a aplicação da Lei $\mathrm{n}^{\circ} \quad 8.666 / 1993$ - a Lei de Licitação - aos procedimentos licitatórios da autora. Com a decisão da ministra, a determinação do TCU ficará suspensa, até julgamento do mérito, e a estatal continuará a adotar regime diferenciado para realizar licitações (STF, 2010, p.1).

Diante dessa liminar

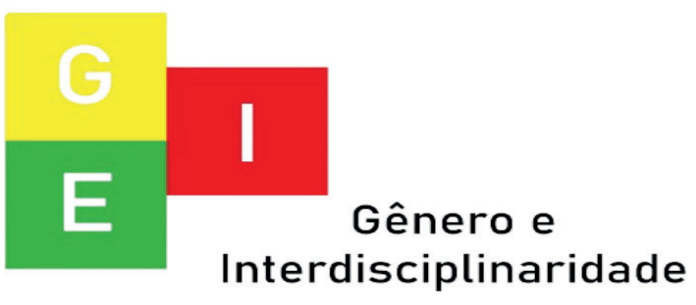


ISSN: 2675-7451

Vol. 02 - n 03 - ano 2021

Editora Acadêmica Periodicojs

concedida pela Ministra Ellen

Gracie, garantiu que a Petrobrás

continuasse usando o procedi-

mento licitatório simplificado es-

tabelecido na Lei $\mathrm{n}^{\circ} 9.478$, de 6 de

agosto de 1997, até o julgamento

do mérito.

O Superior Tribunal de Justiça, considerando que a competência Judicante do Tribunal de Contas seja somente de natureza administrativa, foi que julgou decidindo o seguinte:

A decisão que aprecia as contas dos administradores de valores públicos faz coisa julgada administrativa no sentido de exaurir as instâncias administrativas, não sendo mais suscetível de revisão naquele âmbito. Não fica, no entanto, excluída de apreciação pelo Poder Judiciário, porquanto nenhuma lesão de direito pode dele ser subtraída. 6 .
$\mathrm{O}$ art. $5^{\circ}$, inc. $\mathrm{XXXV}$

da $\mathrm{CF} / 88$, dispõe que “a lei não excluirá da apreciação do Poder Judiciário lesão ou ameaça a direito". 7. A apreciação pelo Poder Judiciário de questões que foram objeto de pronunciamento pelo TCU coaduna-se com a garantia constitucional do devido processo legal, porquanto a via judicial é a única capaz de assegurar ao cidadão todas as garantias necessárias a um pronunciamento imparcial. (STJ - REsp. 472.399/ AL - $1^{\mathrm{a}}$ Turma DJ 19.12.2002 - p. 00351 - Rel. Min. José Delgado).

Em outro momento o Superior Tribunal de Justiça, também considerou os julgamento do TCU como de cunho técnico administrativo, como pode ser

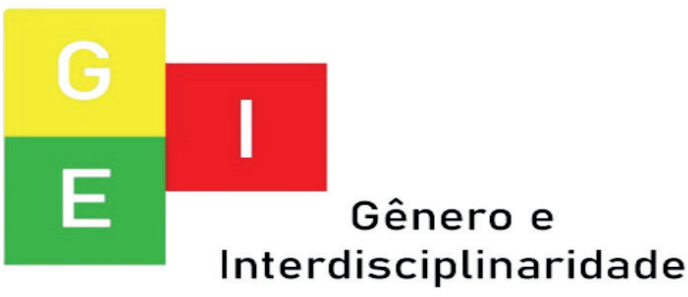


ISSN: 2675-7451

Vol. 02 - n 03 - ano 2021

Editora Acadêmica Periodicojs

visto no julgado a seguir:

O míster desempenhado pelos Tribunais de Contas, no sentido de auxiliar os respectivos Poderes Legislativos em fiscalizar, encerra decisões de cunho técnico-administrativo e suas decisões não fazem coisa julgada, justamente por não praticarem atividade judicante. Logo, sua atuação não vincula o funcionamento do Poder Judiciário, o qual pode, inclusive, revisar as suas decisões por força Princípio Constitucional da Inafastabilidade do Controle Jurisdicional (art. 5', XXXV, da Constituição). (REsp 1032732/CE, Rel. Ministro BENEDITO GONÇALVES, PRIMEIRA TURMA, julgado em 25/08/2015, DJe 08/09/2015).
Também é possível iden-

tificar o mesmo posicionamento em outros julgamentos feitos em diferentes Tribunais, conforme a síntese feita por Bezerra Filho (2017, p. 5):

A lei não excluirá da apreciação do Poder Judiciário lesão ou ameaça a direito, nos termos do disposto no art. $5^{\circ}, \mathrm{XXXV}$ , da $\mathrm{CF} / 88$. II $-\mathrm{A}$ decisão do Tribunal de Contas da União que aprecia as contas de Prefeitos faz coisa julgada na esfera administrativa, mas está sujeita à apreciação do Poder Judiciário, eis que o direito de ação é público e subjetivo. III - Apelação provida, com o retorno dos autos ao Juízo de origem para regular processamento do feito. TRF1 - APELAÇÃO CIVEL AC 11112 MG 2000.38.00.011112-7 (TRF-1).

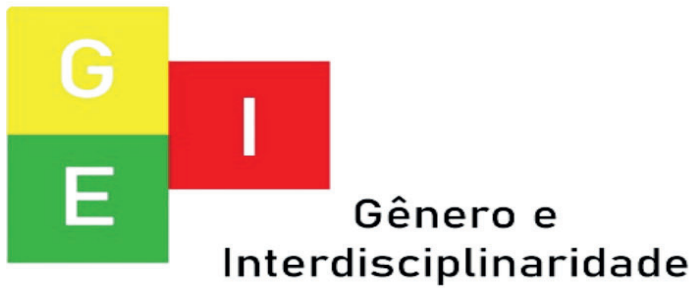


ISSN: 2675-7451

Vol. 02 - n 03 - ano 2021

Editora Acadêmica Periodicojs

Os atos do Tribunal

de Contas, mesmo

os julgamentos, não

são discricionários,

mas vinculados. Os

primeiros possuem

mérito - que é insin-

dicável, consoante o

entendimento (ainda)

dominante -, sendo

que os segundos são

plenamente vincula-

dos e questionáveis,

nos limites admiti-

dos por tal catego-

ria de atos adminis-

trativos. O que ora

importa sublinhar,

de forma clara - já

que é esse o preciso

objeto da pretensão recursal -, é a efetiva possibilidade de revisão das decisões administrativas prolatadas pelo Tribunal de Contas da União, pelo Poder Judiciário, ao qual compete o controle e a tutela jurisdicionais, nos termos dos balizamentos supra delineados (art. 5 $5^{\circ}, \mathrm{XXXV}$ da CF; e art. 745, V, do CPC). Dou provimento ao recurso, para anular a sentença recorrida. (TRF2 - APELAÇÃO CIVEL: AC 340934 RJ 2000.51.01.0163205 Relator(a): Desembargador Federal POUL ERIK DYRLUND Julgamento: 12/06/2007 Órgão Julgador: OITAVA TURMA ESPECIALIZADA Publicação: DJU Data::15/06/2007 Página: 381.

Nesse sentido, verifica-se que a Jurisprudência passou a determinar o controle judicial das decisões dos tribunais de contas, sendo que as decisões desses tribunais, podem ser revistas pelo poder judiciário.

\section{CONSIDERAÇÕES FINAIS}

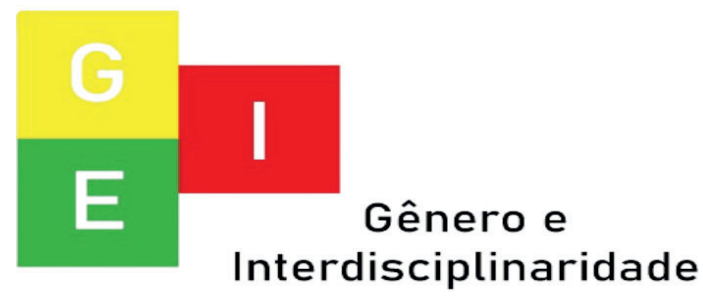


ISSN: 2675-7451

Vol. 02 - n 03 - ano 2021

Editora Acadêmica Periodicojs

Fazendo uma retros- Brasileira em 1824 que o Erário

pectiva do que foi estudado neste trabalho e lembrando que o objetivo de estudo foi discutir o controle judicial das decisões dos tribunais de contas, assim como seus limites de atuação. Fazendo um breve panorama histórico dos tribunais de conta constatou-se que os Tribunais de Contas brasileiros seguem o modelo francês, sendo que esse mesmo modelo é seguido também em outros países, juntamente com as normas jurídicas tradicionais de cada país.

Verificou-se que historicamente o Tribunal de Contas, no Brasil, foi criado pela coroa portuguesa aproximadamente em 1680, quando foram instituídas as Juntas das Fazendas das Capitanias e a Junta da Fazenda do Rio de Janeiro. E foi com a Independência do Brasil e a promulgação da primeira Constituição
Régio passou a ser chamado de Tesouro Público, mas o Tribunal de Contas só foi criado com a instituição da República e as reformas político-administrativas, assim em 1890 foi criado o Tribunal de Contas da União. A partir de então as funções e competência do TCU sofreram várias modificações em cada Constituição promulgada, e foi com a edição da Constituição Federal de 1988, que o Tribunal de Contas passou "a ter sua jurisdição e competências próprias e ampliadas".

Constatou-se que a atuação do tribunal de contas da união segue o que estabelece o artigo 71 da Carta Magna de 1988, sendo a natureza jurídica auxiliar o poder legislativo na fiscalização financeira, contábil e orçamentária dos entes públicos.

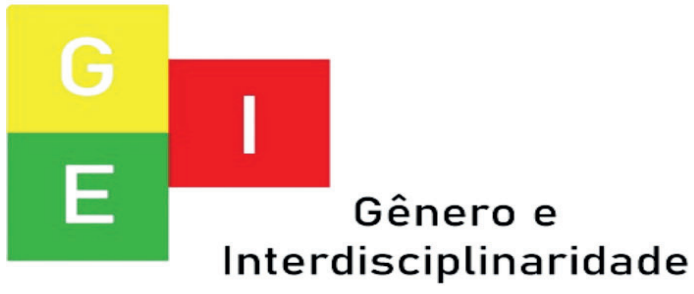


ISSN: 2675-7451

Vol. 02 - n 03 - ano 2021

Editora Acadêmica Periodicojs

Sendo as funções do Tribunal de Contas da União fiscalizar, consultar, informar, judicar, sancionar, corrigir, normatizar e ouvir, educar e orientar. A seguir apresenta-se cada uma dessas funções.

Quanto a atuação jurisdicional do tribunal de contas, verificou-se que embora a Carta Magna de 1988 tenha preconizado autonomia e poderes amplos de fiscalização dos entes públicos, limitou sua atuação em auxiliar do Poder Legislativo, com competência para julgar no âmbito técnico-administrativo. Observou-se também que a jurisprudência moderna inovou ao revisar julgadas do Tribunal de Contas tendo como base os princípios da proporcionalidade, moralidade, eficiência e na teoria dos motivos determinantes, assim como o princípio da inafastabilidade da tutela jurisdicio- nal. Enfim, concluiu-se que os Tribunais de Contas podem ter suas decisões revisadas pelo Poder Judiciário, tanto nos aspectos formais como materiais.

\section{REFERÊNCIAS}

ALEMANHA. Informações sobre controle financeiro estatal na Alemanha. Disponível em < http://www.rechnungshof.de/> Acesso em 30 abr. 2020. (Traduzido pelo autor)

BARRETO, Wagner da Silva. Tribunais de contas: conceito, funções, competências, histórico, natureza jurídica e acórdão do TCU em anexo. Âmbito Jurídico, 1 de junho de 2016. Disponível em $<$ https://ambitojuridico.com.br/cadernos/direito- constitucional/ tribunais-de-contas-conceito-funcoes-competencias-histori-

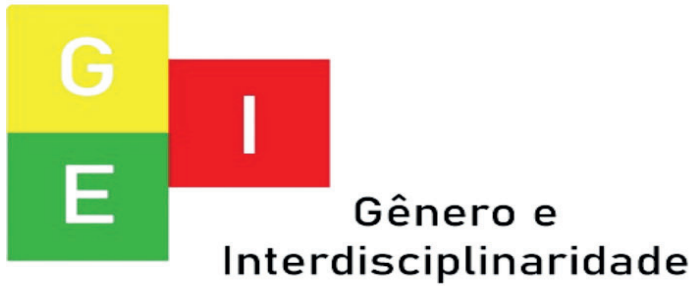


ISSN: 2675-7451

Vol. 02 - n 03 - ano 2021

Editora Acadêmica Periodicojs

co-natureza- juridica-e-acordao-do-tcu-em-anexo/> Acesso em 23 abr. 2020.

BRASIL. Constituição da República dos Estados Unidos do Brasil, de 24 de janeiro de 1967.

BEZERRA FILHO, Aluízio. A judicialização das decisões dos Tribunais de Contas. Meu

BRASIL. Constituição da República Federativa do Brasil, 5 de Site Jurídico, 22 de outubro de 1988. maio de 2017. Disponível em $<$ https://meusiteDI PIETRO, Maria Sylvia juridico.editorajuspodivm.com. Zanella. Direito administrativo. br/2017/05/22/judicializacao-das- 17.ed. São Paulo: Atlas, 2003. decisoes-dos-tribunais-de-contas/ >Acesso e: 3 maio 2020.

EUA - ESTADOS UNIDOS DA AMÉRICA. U.S. Government BRASIL. Constituição da RepúAccountability Office (GAO). blica dos Estados Unidos do BraDisponível em $<$ https://www. sil, de 24 de Fevereiro de 1891.

gao.gov/about/> Acesso em 30 abr. 2020. Traduzido pelo autor.

BRASIL. Constituição da República dos Estados Unidos do Brasil, de 16 de Julho de 1934.

FERNANDES, Jorge Ulisses Jacoby. Os limites do poder fiscalizador do Tribunal de Contas do BRASIL. Constituição da RepúEstado. Brasília, v. 36, n. 142, p. blica dos Estados Unidos do Bra167-199, abr./jun. 1999. sil, de 18 de setembro de 1946 .

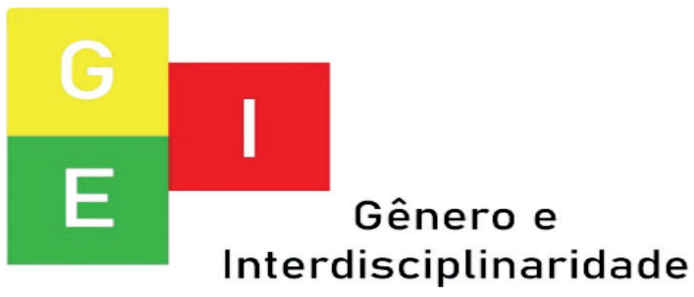


ISSN: 2675-7451

Vol. 02 - n 03 - ano 2021

Editora Acadêmica Periodicojs

JEAN, Pascal. Parlement et direito-administrativo/o-controcour des comptes. 2013. Dis- le-judicial-das- decisoes-dos-triponível em $<$ https://www.cairn. bunais-de-contas/> Acesso em: 2 info/revue-pouvoirs-2013-3-pa- maio 2020.

ge-107.htm> Acesso em 30 abr. 2020.

MELO, Paulo Sérgio Ferreira. A natureza jurídica das deciLIMA, Luiz Henrique. Controle sões dos Tribunais de Contas. externo. 2.ed. revisada, ampliada Âmbito Jurídico, 1 de junho de e atualizada até a súmula vinculante $\mathrm{n}^{\mathrm{o}} 3$ - STF e a Emenda Constitucional $n^{0} 55 / 2007$. Rio de Janeiro: Elsever, 2008.

2011. Disponível em $<$ https:// ambitojuridico.com.br/cadernos/ direito-administrativo/a-natureza-juridica-das- decisoes-dos-tribunais-de-contas/> Acesso em

LIMA, Luiz Henrique. Controle 30 abr. 2020.

externo: teoria, jurisprudência e mais de 400 questões. Rio de Janeiro: Campus, 2007.

PORTAL DO TRIBUNAL DE CONTAS DA UNIÃO. Institucional. Competência. DisponíLOPES FILHO, Alexandre Pa- vel em <https://portal.tcu.gov.br/ checo. O controle judicial das de- institucional/conheca-o-tcu/comcisões dos tribunais de contas. petencias/> Acesso em 30 abr. Âmbito Jurídico, $\quad 1 \quad 2020$. fevereiro de 2012 .

Disponível em $<$ https://amRODRIGUES, Álvaro Pinto. A bitojuridico.com.br/cadernos/ atuação do tribunal de contas

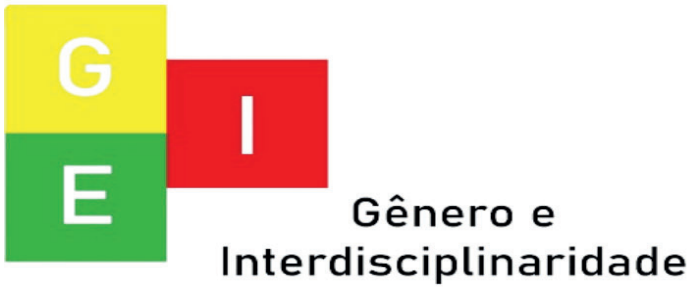


da união na gestão compartilhada da saúde - análise a partir do controle social. Dissertação Mestrado. Universidade Luterana do Brasil. Canoas, 2009.

SANTOS, Márcia Walquiria Batista; QUEIROZ, João Eduardo Lopes. Direito administrativo. São Paulo: Campus Jurídico, 2013.

SILVA, Cláudia Bressan. O limite de jurisdição dos Tribunais de Contas e o princípio do juiz natural. Direito e Democracia, Canoas, v.17, n.1, p. 147-165, já/jun. 2016.

\section{SUPERIOR TR I BU N A L}

FEDERAL. Súmula $\mathrm{n}^{\mathrm{o}}$ 347. Disponível em $<$ http://www.stf.jus.br/portal/jurisprudencia/menuSumarioSumulas.asp?sumula=2149 $>$ Acesso em: 28 abr. 2020.

\section{SUPERIOR TRIBUNAL FEDE-}

RAL. Supremo Tribunal Federal STF - Mandado De Segurança: MS 7280. Disponível em $<$ https://stf.jusbrasil.com.br/jurisprudencia/696732/mandado-de-seguranca-ms-7280 $>$ Acesso em: 28 abr. 2020.

TRIBUNAL DE CONTAS DA UNIÃO. Áreas de atuação do controle externo. Disponível em $<$ https://portal.tcu.gov.br/controle-e-fiscalizacao//> acesso em: 25 abr. 2020.

TRIBUNAL DE CONTAS DA UNIÃO. Estrutura Organizacional. Disponível em $<$ https:// portal.tcu.gov.br/institucional/estrutura-organizacional/> acesso em: 25 abr. 2020.

TRIBUNAL DE CONTAS EUROPEU. Disponível em

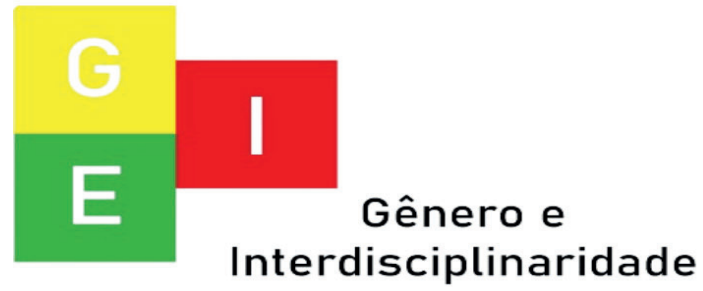


$<$ https://op.europa.eu/webpub/

eca/annual-activity-report-2019/

pt/index.html> Acesso em: 30

abr. 2020 .

TRIBUNAL REGIONAL FE-

DERAL $5^{\mathrm{a}}$ Região - Apelação Civel: AC 380126 PE 2005.83.02.000431-8. Relator(a): Desembargador Federal Élio Wanderley de Siqueira Filho (Substituto). Órgão Julgador: Primeira Turma. Julgamento: 11/07/2007)

ZAMPARETTI, Aloísio de Freitas. O controle externo da administração pública exercido pelo tribunal de contas da união

- TCU. Monografia. Complexo de Ensino Superior de Santa Catarina - CESUSC. Faculdade de Ciências Sociais de Florianópolis - FCSF. Florianópolis, 2009.

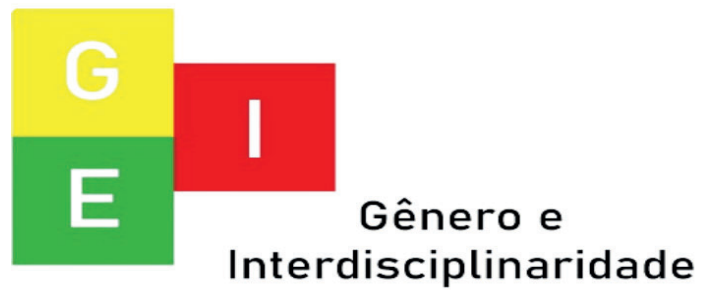

